\title{
Connexin 43 expression at an early stage in dog mandibles by $\beta$-TCP
}

\author{
Miho HAYASHI ${ }^{1}$, Tetsuji TAKAHASHI ${ }^{1}$, Kazuko KAWAGUCHI ${ }^{2}$, Takao WATANABE ${ }^{2}$, Jian ZHAO ${ }^{1}$ \\ and Yoshimitsu ABIKO ${ }^{1,3}$ \\ ${ }^{1}$ Department of Biochemistry and Molecular Biology, Nihon University School of Dentistry at Matsudo, 2-870-1 Sakaecho-nishi, Matsudo, Chiba \\ 271-8587, Japan \\ ${ }^{2}$ Department of Oral Anatomy, Kanagawa Dental College, 82 Inaokacho, Yokosuka, Kanagawa 238-8580, Japan \\ ${ }^{3}$ Research Institute of Oral Sciences, Nihon University School of Dentistry at Matsudo, 2-870-1 Sakaecho-nishi, Matsudo, Chiba 271-8587, Japan \\ Corresponding author, Yoshimitsu ABIKO; E-mail: abiko.yoshimitsu@nihon-u.ac.jp
}

\begin{abstract}
$\beta$-TCP was implanted into bone defects of dog mandibles, and gene expression profiles were examined using DNA microarray. An implant drill was used to make bone defects, and then $\beta$-TCP was filled into bone defects. All specimens were taken out, total RNA was isolated, and levels were analyzed using Affymetrix GeneChip. Higher mRNA levels of connexin 43 (Cx43) and Cx45 were observed in $\beta$-TCP-implanted samples compared with controls. The enhancement of $\mathrm{Cx} 43$ and $\mathrm{Cx} 45$ by $\beta$-TCP was confirmed by RT-PCR and real-time RT-PCR. Since Cx43 is known to express in bone-forming regions and is involved in osteogenesis through gap junctional intercellular bone-cell communication (GJIB), immunohistochemical staining was also examined and demonstrated Cx43 protein expression was increased in $\beta$-TCP-implanted bone. $\mathrm{Cx} 43$ plays a role in osteogenesis through GJIB; therefore, the stimulation of $\mathrm{Cx} 43$ expression by $\beta$-TCP might be a mechanism of accelerating wound healing and bone formation.
\end{abstract}

Keywords: $\beta$-TCP, Connexin 43, Bone formation, Dog mandible

\section{INTRODUCTION}

Technologies to repair orofacial skeletal defects take place at the same time with surgical therapies using bone grafts ${ }^{1)}$ and synthetic materials ${ }^{2}$. Calcium phosphate ceramics have been considered for use as synthetic bone graft substitutes. Furthermore, commercial $\beta$-tricalcium phosphate $(\beta$-TCP) has been clinically used. Numerous in vivo and in vitro assessments have reported that $\beta$-TCP has excellent biocompatibility and osteoconductivity, and supports the attachment, differentiation and proliferation of relevant cells such as osteoblasts and mesenchymal cells ${ }^{3-6)}$. An additional advantage is that $\beta$-TCP exhibits a faster degradation rate than crystalline hydroxyapatite ${ }^{7}$. $\beta$-TCP might be a suitable bone substitute that will biodegrade and be replaced by newly mineralizing bone tissue without fibrous tissue proliferation. Furthermore, the use of $\beta$-TCP as an alloplastic bone graft material for sinus grafting procedures has also received increasing attention in oral implant therapy ${ }^{8}$. However, very little is known about the molecular basis for mechanisms enhancing bone formation by $\beta$-TCP.

Biologically interactive biomaterials could improve the treatment of bone defects, and an understanding of developmental processes might help identify strategies and materials that can be used in tissue engineering. One such strategy that might advance tissue engineering is cell-cell communication. Gap junction intercellular communication is the most direct way of achieving such signalling. Gap junction communication through connexin-mediated junctions, in particular connexin 43 (Cx43) plays a major role in bone development ${ }^{9}$. In this

Color figures can be viewed in the online issue, which is available at J-STAGE.

Received Apr 27, 2010: Accepted Sep 7, 2010

doi:10.4012/dmj.2010-058 JOI JST.JSTAGE/dmj/2010-058 study, to understand the usefulness of $\beta$-TCP in bone formation, $\beta$-TCP was implanted into dog mandible defects in beagle dogs, and gene expression profiles were examined using DNA microarray technology focused on the $\mathrm{Cx}$ gene family. The $\mathrm{Cx} 43 \mathrm{mRNA}$ levels from DNA microarray were confirmed using RT-PCR and real-time $\mathrm{PCR}$, moreover, $\mathrm{Cx} 43$ protein expression was examined by immuno-histochemistry.

\section{MATERIALS AND METHODS}

\section{Implantation of $\beta$-TCP}

Beagle dogs (body weight $13 \pm 2 \mathrm{~kg} ; 10 \mathrm{dogs}$ ) were purchased from Japan SLC (Shizuoka, Japan). The dogs were allowed access to food and water ad libitum at all times and were maintained on a $12 \mathrm{~h}$ light/dark cycle (lights on 8:00 to $20: 00$ ) at $23 \pm 1^{\circ} \mathrm{C}$. All beagle dogs were maintained and used in accordance with the guidelines of the care and use of laboratory animals of Kanagawa Dental College (Approval \#: 08.12.TTH). There were two experimental groups: the $\beta$-TCP scaffold implant group and the no implant control. The left and right mandibles of beagle dogs were divided randomly into three time groups according to the expected time when they would be sacrificed.

All beagle dogs were injected with sodium pentobarbital (Somnopentyl ${ }^{\circledR}$, Kyoritsu Seiyaku, Tokyo, Japan) at a dose of $35 \mathrm{mg} / \mathrm{kg}$. The dogs then had their premolar teeth extracted. After three months' healing, the sockets of mandible defects $(4.5 \mathrm{~mm}$ diameter, $8 \mathrm{~mm}$ length) were made in the mandible bone using an implant drill with physiologic saline cooling under anaesthesia. The $\beta$-TCP was purchased $(\beta$-TCP-100, $>99 \%$ pure, Taihei Chemicals Limited, Japan) and crushed to 500-800 $\mu \mathrm{m}$ diameter particles, and was filled 
into left or right mandible bone defects (200 mg per one defect). After surgery, each beagle dog received an intramuscular injection of sodium ampicillin (Viccillin ${ }^{\circledR}$, Meiji, Tokyo, Japan) at a dose of $100 \mathrm{mg}$ per $\mathrm{kg}$ body weight. All specimens (4.5 $\mathrm{mm}$ diameter, $8 \mathrm{~mm}$ length) were taken out in a cylinder at 4,7 and 14 days after surgery, and immersed into RNA stabilization solution (RNA later ${ }^{\circledR}$, Applied Biosystems, Ambion, USA).

\section{RNA preparation}

Total RNA was extracted from each bone biopsy using an optimised RNA extraction protocol based on the RNeasy ${ }^{\circledR}$ Fibrous Tissue Mini Kit Isolation System (Qiagen, CA, USA) according to the manufacturer's protocol. One piece of a biopsy (a maximum of a $3 \mathrm{~mm}$ cube $=25-35 \mathrm{mg}$ of tissue) was placed into $350 \mathrm{~mL}$ of lysis buffer (Buffer RLT, from the isolation kit) in a Lysing Matrix A tube (FastPrep ${ }^{\circledR}$ System, MP Biomedicals, Tokyo, Japan) and homogenised six times at $6.0 \mathrm{~m} / \mathrm{sec}$ for $45 \mathrm{sec}$ each. Samples were processed using the RNeasy Isolation System following the NanoDrop manufacturer's instructions. RNA quality was confirmed by calculating the $\mathrm{OD}_{260 / 280}$ ratio via a spectrophotometer, and its integrity was verified using Agilent RNA 6000 nano kits (Agilent, Santa Clara, CA, USA).

\section{DNA microarray analysis}

The protocol for DNA microarray processing was carried out according to the GeneChip ${ }^{\circledR}$ 3' IVT express kit user manual (Affymetrix, Santa Clara, CA, USA). Total RNA samples (100 ng) were subjected to two-cycle target labelling according to the Affymetrix instructions. Antisense complimentary RNA (cRNA) derived from double-strand complimentary DNA (cDNA) was labelled in the presence of biotinylated deoxyribonucleotide triphosphate (dNTP) derivatives to produce cRNA probes. The probes were then fragmented and hybridized on the GeneChip ${ }^{\circledR}$ Canine Genome 2.0 Array (Affymetrix; 38,000 genes). After hybridization, the arrays were scanned using the GeneChip ${ }^{\circledR}$ Scanner 3000 and the scanned images were analyzed using GeneChip ${ }^{\circledR}$ operating software (Affymetrix). Flag analysis, to demonstrate the presence $(\mathrm{P})$ or absence $(\mathrm{A})$ of signals, was evaluated and intensity normalization was performed. Data analysis was then performed using the GeneSpring (Silicone Genetics, Redwood, CA, USA) software package.

\section{RT-PCR and real-time RT-PCR analysis}

RT-PCR and real-time RT-PCR reactions were carried out using a DNA thermal analyser (RCX43-Gene ${ }^{\mathrm{TM}} 6000$; Corbett Life Science, Sydney, Australia). Amplification by PCR was started with an initial incubation at $95^{\circ} \mathrm{C}$ for 15 sec to activate the Taq DNA polymerase, and then performed at $95^{\circ} \mathrm{C}$ for $5 \mathrm{sec}$ and $56^{\circ} \mathrm{C}$ for $15 \mathrm{sec}$ for the appropriate number of cycles. RT-PCR products were electrophorezed on a $1.5 \%$ agarose gel, followed by staining with ethidium bromide to examine the intensity and size of PCR products. Each assay was normalized to glyceraldehyde-3-phosphate dehydrogenase (GAPDH)
mRNA levels.

Real-time PCR was carried out with SYBR Premix Ex Taq ${ }^{\text {TM }}$ (Perfect Real-Time PCR, Takara, Japan) and a green PCR kit (Qiagen). To calculate gene expression fold changes, the initial template concentration was derived from the cycle number at which the fluorescent signal crossed the threshold in the exponential phase of the real-time PCR reaction. The mRNA copy unit was given by the cycle threshold value from the fluorescent signal of all the samples, including the standard curve and target genes, following the method provided by Corbett Life Science using the RCX43-Gene ${ }^{\mathrm{TM}} 6000$ software. Details were described in an operation manual (version 1.7.40, 2006).

The DNA primer sequences were 5'atgagcagtctgcetttcgt-3' (the forward primer for $\mathrm{Cx} 43$ gene); 5'-tctgcttcaagtgcatgtcc-3' (the reverse primer for $\mathrm{Cx} 43$ gene), predicted size=249 bp; 5'-atggtgttacaggctttgc-3' (the forward primer for $\mathrm{Cx} 45$ gene); 5'-gccttgttttgcttgtaggc-3' (the reverse primer for Cx45 gene), predicted size $=241 \mathrm{bp} ; 5$ '-atcaccatcttccaggag3' (the forward primer for GAPDH); and 5'atcgactgtggtcatgag-3' (the reverse primer for GAPDH gene), predicted size $=318 \mathrm{bp}$. Values were calculated as means \pm standard deviation (SD), $(n=3)$. Comparisons were made between the two groups using a Student's $t$ test.

\section{Histological analysis}

Cylindrical specimens (4.5 $\mathrm{mm}$ diameter, $8 \mathrm{~mm}$ length) were collected and fixed in $10 \%$ formalin for $48 \mathrm{~h}$, decalcified in $10 \%$ EDTA (0.1 M phosphate buffer, $\mathrm{pH}$ 7.4) for 4 weeks, embedded in paraffin, and cut into 5 mm-thick sections. The sections were stained with hematoxylin and eosin (H-E), photographed and evaluated under a light microscope.

\section{Immunohistochemistry}

Formalin-fixed, paraffin-embedded specimens were subjected to antigen retrieval, endogenous peroxidase blocking (30 min) and rinsed with phosphate-buffered saline (PBS). Immunostaining was performed using Elite ABC kits (Vector, Burlingame, CA, USA) and diaminobenzidine (Kirkegaard \& Perry, Gaithersburg, $\mathrm{MD}$, USA) as a chromogen using an anti-Cx43 polyclonal antibody (1:400; Sigma, Japan) at $4^{\circ} \mathrm{C}$ overnight. Peroxidase-conjugated rabbit anti-mouse immunoglobulin diluted 1:10 in PBS supplemented with 2 -vol\% heat-inactivated normal human serum was used. The second antibody was incubated at room temperature for $30 \mathrm{~min}$. Peroxidase activity was visualized with 0.06\% diaminobenzidine (Walter, Kiel, Germany) and 0.01 vol\% $\mathrm{H}_{2} \mathrm{O}_{2}$. Endogenous peroxidase activity was blocked by a reagent (Dako REAL Peroxidase-Blocking Solution; S2023, Carpinteria, CA, USA). After incubation with rabbit anti-Cx43 polyclonal antibody (1:400; Sigma) at $4^{\circ} \mathrm{C}$ for overnight, the specimens were rinsed with PBS and incubated at room temperature for $1 \mathrm{~h}$ with secondary antibody conjugated with Alexa Fluor 488 donkey anti-rabbit IgG (H+L) (1:1000; Molecular Probes, 
OR, USA). After rinsing with PBS, all specimens were colour-developed with ProLong Gold Antifade Reagent with DAPI (Molecular Probes). The immunostaining of all specimens was performed simultaneously to ensure the same antibody reaction and DAPI exposure conditions.

\section{RESULTS}

Fig. 1 shows photomicrographs of H-E stained crosssections through bone samples collected from dogs in the control and $\beta$-TCP groups 4,7 or 14 days after surgery. The photomicrograph area were focused on new bone formation area, $\beta$-TCP particles were remained around area shown. At 4 and 7 days, the $\beta$-TCP group showed a higher bone formation rate when compared with control. In contrast, there did not seem to be a significant change between $\beta$-TCP and the control treatment at 14-day.

$\beta$-TCP altered the expression of many genes as shown in the scatter plot analysis (Fig. 2). Among altered genes, we found that $\mathrm{Cx} 43$ and $\mathrm{Cx} 45$ mRNA levels were enhanced more than two-fold. Table 1 shows the raw

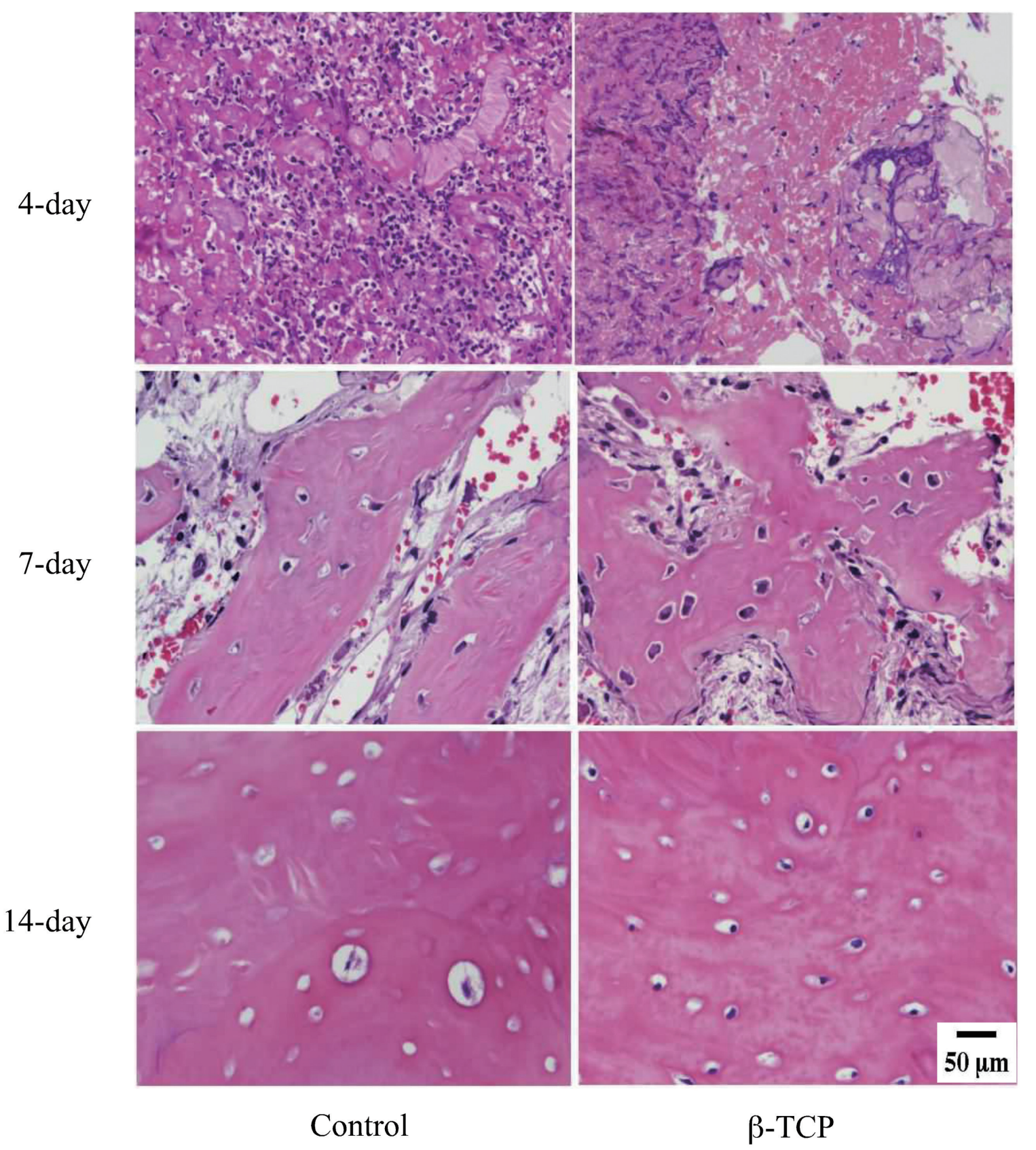

Fig. 1 Histological micrographs $(\mathrm{H}-\mathrm{E}, \times 200)$ of specimens from control and $\beta$-TCP group at 4-, 7- and 14-day after surgery. 

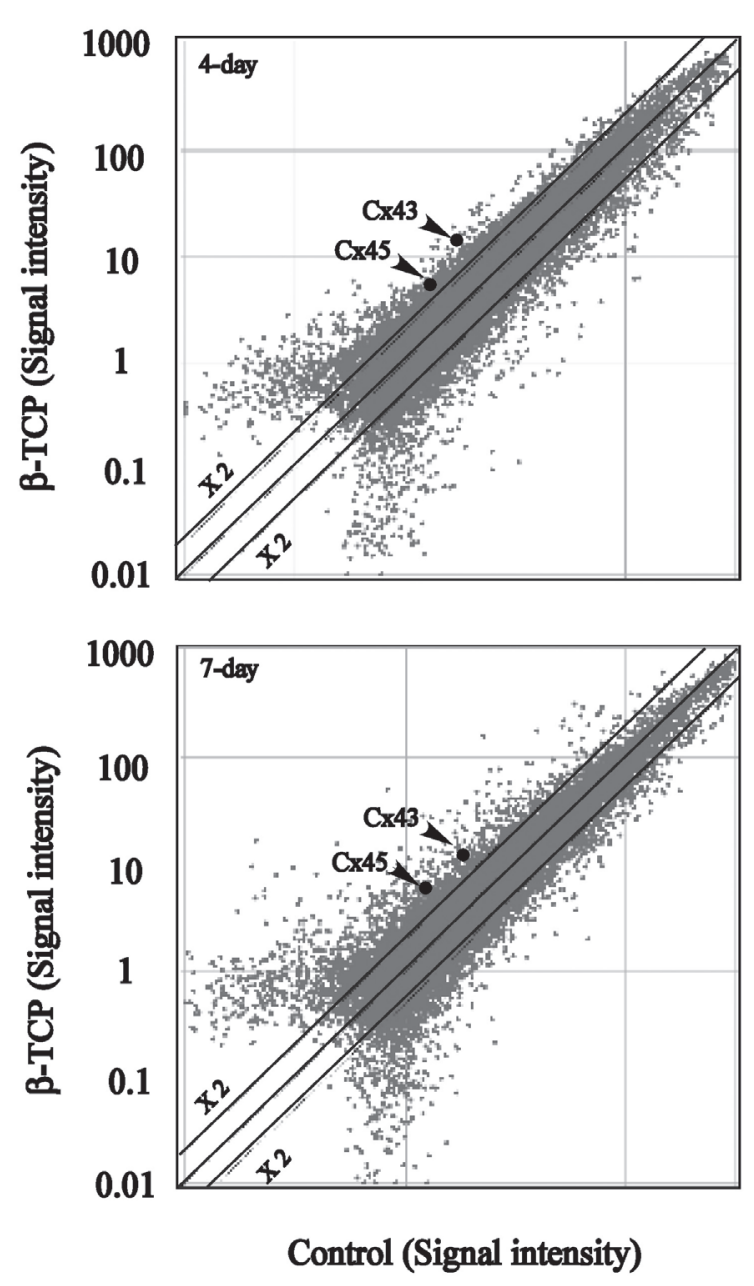

Fig. 2 A scatter plot of the mRNA levels of the Cx family expressed in $\beta$-TCP implantation. Signal intensities of $\mathrm{Cx} 43$ and $\mathrm{Cx} 45$ were normalised with GAPDH mRNA levels. intensity signals of the Cx gene family's mRNA levels in dog mandibles with or without $\beta$-TCP implantation from the Affymetrix GeneChip ${ }^{\circledR}$ analysis results at 4 and 7 days. The $\mathrm{Cx}$ gene family members expressed in mandibles were selected by Flag analysis as present $(\mathrm{P})$ with more than two-fold changes, and identified as $\mathrm{Cx} 43$ and $\mathrm{Cx} 45$.

Scatter plots of the mRNA levels of $\mathrm{Cx} 43$ and $\mathrm{Cx} 45$ for 4 and 7 days are shown in Fig. 2. The gene for $\mathrm{Cx} 43$ was expressed with a 3.5- and 2.7-fold change, while Cx45 demonstrated 2.9 and 1.0-fold changes in $\beta$-TCP implanted tissues compared with the controls, respectively.

Since Cx43 and Cx45 mRNA levels were highly elevated in the $\beta$-TCP-treated group and is known to be involved in bone formation, RT-PCR was performed. As shown in Fig. 3, the mRNA levels were higher than in the non-implantation controls in all samples. By

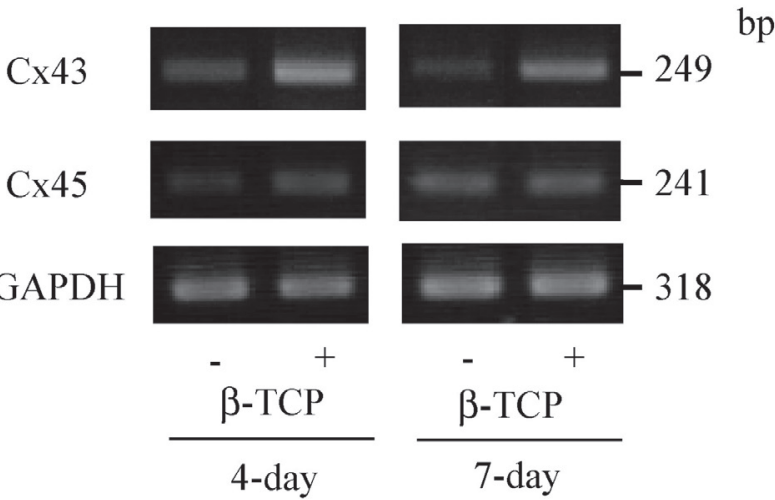

Fig. 3 RT-PCR analysis of the mRNA levels of Cx43 and $\mathrm{Cx} 45$. An ethidium bromide-staining pattern of the amplified PCR products after agarose gel electrophoresis.

Table 1 Raw intensity signals shown in GeneChip

\begin{tabular}{|c|c|c|c|c|c|c|c|}
\hline \multirow{3}{*}{ Gene } & \multirow{3}{*}{ Genebank ID } & \multicolumn{3}{|c|}{ 4-day } & \multicolumn{3}{|c|}{ 7-day } \\
\hline & & \multicolumn{2}{|c|}{$\beta$-ТCP } & \multirow{2}{*}{ Fold* } & \multicolumn{2}{|c|}{$\beta$-TCP } & \multirow{2}{*}{ Fold* } \\
\hline & & - & + & & - & + & \\
\hline $\mathrm{Cx} 26$ & XM_543177 & $0.27(\mathrm{~A})$ & $3.39(\mathrm{~A})$ & - & $0.34(\mathrm{~A})$ & $2.37(\mathrm{~A})$ & - \\
\hline $\mathrm{Cx} 29$ & XM_546968 & $12.98(\mathrm{P})$ & $12.14(\mathrm{P})$ & 0.8 & $0.88(\mathrm{~A})$ & $1.56(\mathrm{~A})$ & - \\
\hline $\mathrm{Cx} 30$ & XM_539605 & $20.43(\mathrm{~A})$ & $18.03(\mathrm{~A})$ & - & $18.14(\mathrm{~A})$ & $22.01(\mathrm{~A})$ & - \\
\hline Cx32 & XM_538073 & $1.66(\mathrm{~A})$ & $1.23(\mathrm{~A})$ & - & $2.48(\mathrm{~A})$ & $1.51(\mathrm{~A})$ & - \\
\hline $\mathrm{Cx} 37$ & XM_539602 & $19.11(\mathrm{~A})$ & $13.75(\mathrm{~A})$ & - & $36.72(\mathrm{~A})$ & $29.30(\mathrm{~A})$ & - \\
\hline $\mathrm{Cx} 40$ & NM_001017442 & $10.69(\mathrm{~A})$ & $13.76(\mathrm{~A})$ & - & $23.10(\mathrm{P})$ & $21.49(\mathrm{P})$ & 0.7 \\
\hline $\mathrm{Cx} 43$ & NM_001002951 & $61.96(\mathrm{P})$ & $250.10(\mathrm{P})$ & 3.5 & $93.55(\mathrm{P})$ & $323.70(\mathrm{P})$ & 2.7 \\
\hline $\mathrm{Cx} 45$ & NM_001020812 & $26.99(\mathrm{P})$ & $88.60(\mathrm{P})$ & 2.9 & $99.79(\mathrm{P})$ & $125.02(\mathrm{P})$ & 1.0 \\
\hline $\mathrm{Cx} 46$ & XM_543178 & $0.90(\mathrm{~A})$ & $1.08(\mathrm{~A})$ & - & $0.85(\mathrm{~A})$ & $0.65(\mathrm{~A})$ & - \\
\hline Cx50 & XM_540274 & $2.92(\mathrm{~A})$ & $4.13(\mathrm{~A})$ & - & $2.14(\mathrm{~A})$ & $1.13(\mathrm{~A})$ & - \\
\hline
\end{tabular}

Flag $(\mathrm{P})$ or $(\mathrm{A})$ indicate the reliability of the data according to present $(\mathrm{P})$ or absent $(\mathrm{A})$ of gene expression in GeneChip.

* Fold, fold change by normalization against the median of the corresponding to control. 


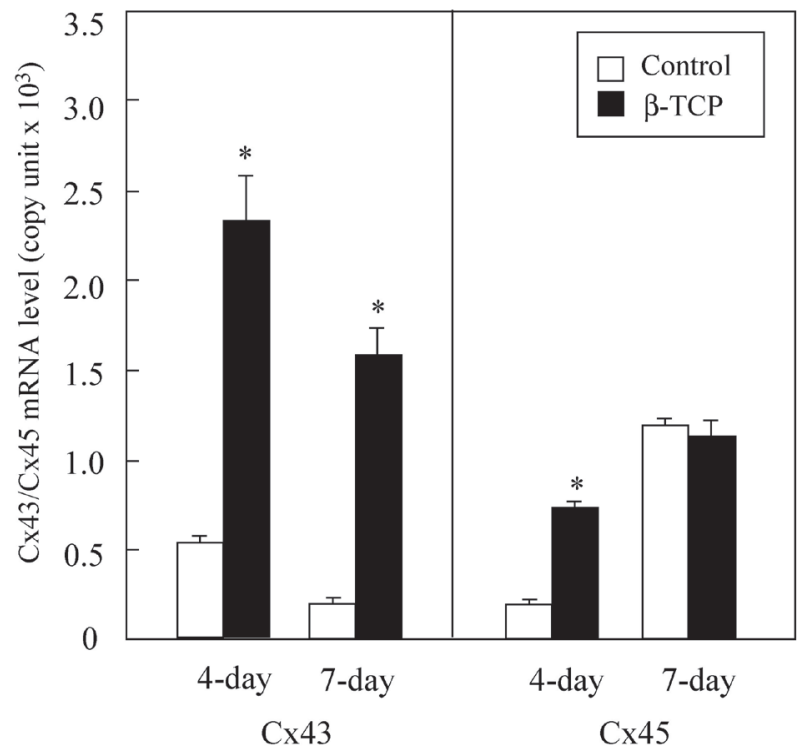

Fig. 4 Real-time analysis of $\mathrm{Cx} 43$ and $\mathrm{Cx} 45$ mRNA levels. Results were expressed as mRNA copy units by normalisation to a housekeeping gene GAPDH. Differences between $\beta$-TCP implantation and controls were determined using a student's $t$ test. ${ }^{*} p<0.001, n=3$.

contrast, the mRNA levels of GAPDH, the housekeeping control gene, showed no differences between each $\beta$-TCP implanted sample and control.

Another experiment to determine the quantities of mRNA levels of the Cx43 gene was performed using real-time RT-PCR. The results were converted to mRNA copy units, and the increase in $\mathrm{Cx} 43$ gene expressions were shown to be significantly different between each $\beta$-TCP implanted sample and control (Fig. 4).

Finally, to examine the phenotypic expression of $\mathrm{Cx} 43$, we performed immunostaining for $\mathrm{Cx} 43$ in dog mandible tissue. The experimental group with $\beta$-TCP implants showed more $\mathrm{Cx} 43$-positive cells than the control group. Staining for Cx43 was found in granulation tissue-forming processes in the mandibles, which showed markedly positive immunostaining in the $\beta$-TCP implanted samples, whereas weak staining was observed in the control group (Fig. 5).

\section{DISCUSSION}

$\beta$-TCP particles in the extraction sockets are clinically osteoconductive $^{10)}$. In fact, at 4 and 7 days, the $\beta$-TCP group showed a higher bone formation rate, although this difference between the $\beta$-TCP and control groups seemed to disappear by day 14 . These findings suggest that tissue healing and bone formation occurred at a relatively early time in our experimental model. Next, we analyzed gene expression profiling in mandible tissues with and without $\beta$-TCP implantation. Specifically, gene expression of bone marker genes including COL1A1, ALP, OPN and TGF- $\beta_{2}$ increased and RANKL and IFN- $\gamma$ expression decreased (data not shown, presented by 88th General of International Association for Dental Research, IADR, 2010, Barcelona, Abstract No. 958, Zhou J et al.: Transcriptome Analysis of $\beta$-TCP Implanted Dog Mandible). Among those genes, the expression levels of the genes for $\mathrm{Cx} 43$ and $\mathrm{Cx} 45$ were found to increase more than 2 -fold in the $\beta$-TCP group when compared to the control group.

When particles of $\beta$-TCP are mixed with a blood clot and surrounded by the bony walls of the alveolar socket, osteogenic cells, including undifferentiated mesenchymal stem cells, start migrating from the existing bone surface between and over the surface of the particles. These cells should change those numbers and cell types during the healing process, and support bone tissue regeneration. Future studies are needed to examine cell type and cellular functions by histochemical approaches.

In a multicellular organism, cell-cell communication through gap junctions plays an essential role in physiological functions and maintaining homeostasis. Gap junctional intercellular communication is a characteristic feature of bone-cell communication. Gap junctions are composed of $\mathrm{Cx}$ proteins. More than 20 isoforms of $\mathrm{Cx}$ have been reported with distinct tissuespecific distributions ${ }^{11)}$, and comprise a family of gap junction structural proteins, which are associated as hexamers in the plasma membranes of adjacent individual cells to form intercellular channels that tightly assemble ${ }^{12,13)}$. Gap junctions are involved in the development, differentiation and homeostasis of intercellular communication channels for small molecules $^{14)}$.

The presence of $\mathrm{Cx} 43$ is required for osteoblastic differentiation and function by forming either gap junctions or "hemichannels". Cx43 allows the participation of cell networks in responses to extracellular stimuli, via propagation of specific signals converging upon Cx-sensitive transcriptional units. The biologic importance of $\mathrm{Cx} 43$, the most abundant gap junction protein in the skeleton, is demonstrated by the skeletal malformations present in oculodentodigital dysplasia, a disease linked to $\mathrm{Cx} 43$ gene (GJA1) mutations, and by the low bone mass and osteoblastic dysfunction in Cx43-ablated mice ${ }^{15}$ ) . These findings suggest that among the $\mathrm{Cx}$ family, $\mathrm{Cx} 43$ is the most abundant isoform in bone and plays an essential role in skeletal development.

The localization and structure of $\mathrm{Cx} 43$ are shown in Fig. 6. Each $\mathrm{Cx} 43$ monomer is a single polypeptide, composed of four transmembrane domains and two small extracellular loops ${ }^{16)}$. In the skeletal system, gap junctions are present in all bone cells, but they are particularly abundant among osteoblasts and osteocytes, and also present at the tip of osteocyte dendritic processes and between these processes and osteoblasts ${ }^{17)}$. Moreover, it has been reported that gap junctions allow cell-cell communication among the osteocytic network ${ }^{18)}$, and $\mathrm{Cx}$ proteins are involved in many aspects of bone cell function, including control of osteoblastic cell 
a

b
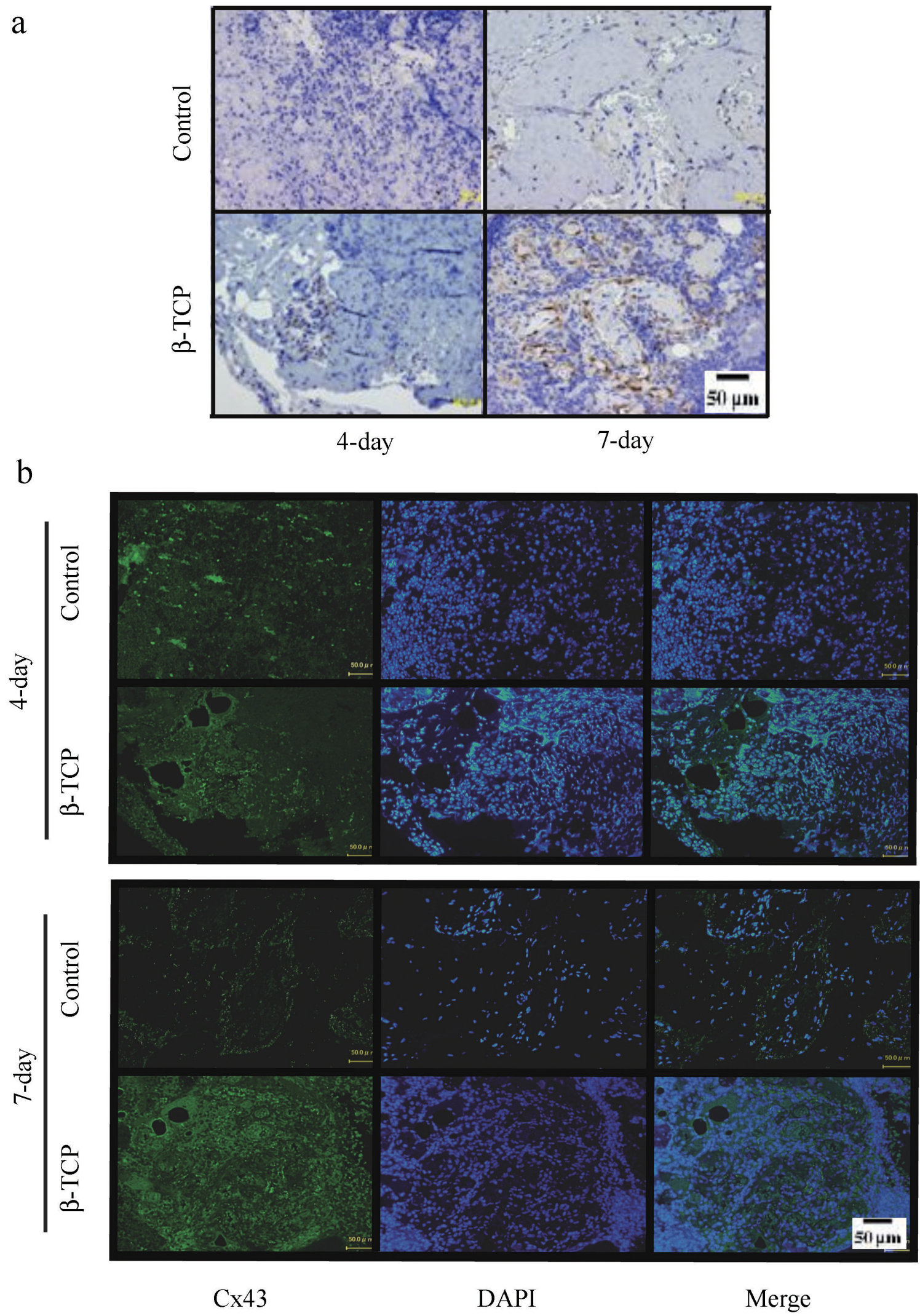

Fig. 5 Immunostaining of $\mathrm{Cx} 43$. Representative photomicrographs of sections of dog mandible stained with anti-Cx43 antibody at day 4 and 7 after $\beta$-TCP implantation. a, Peroxydase activity staining, brown color demonstrated $\mathrm{Cx} 43$; b, fluorescence staining by $\mathrm{Cx} 43$ and DAPI, and merged. 
a

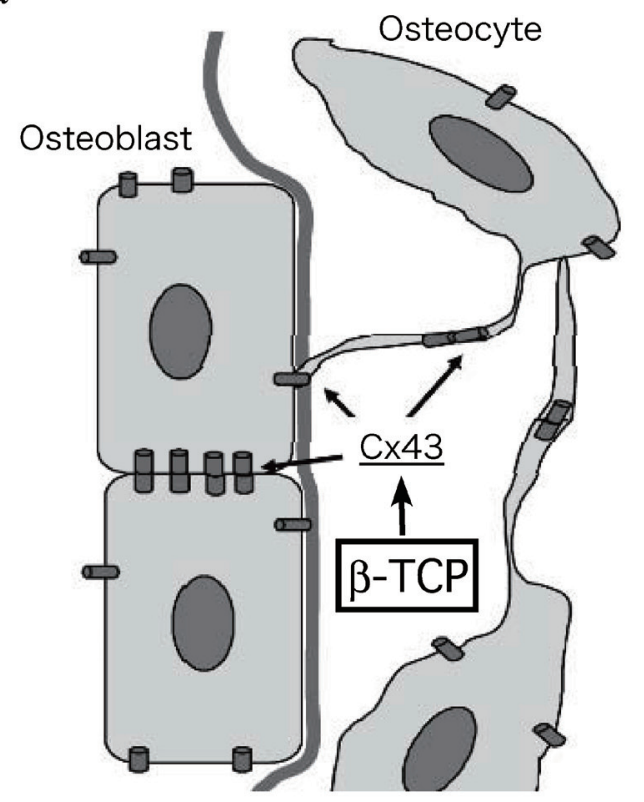

b

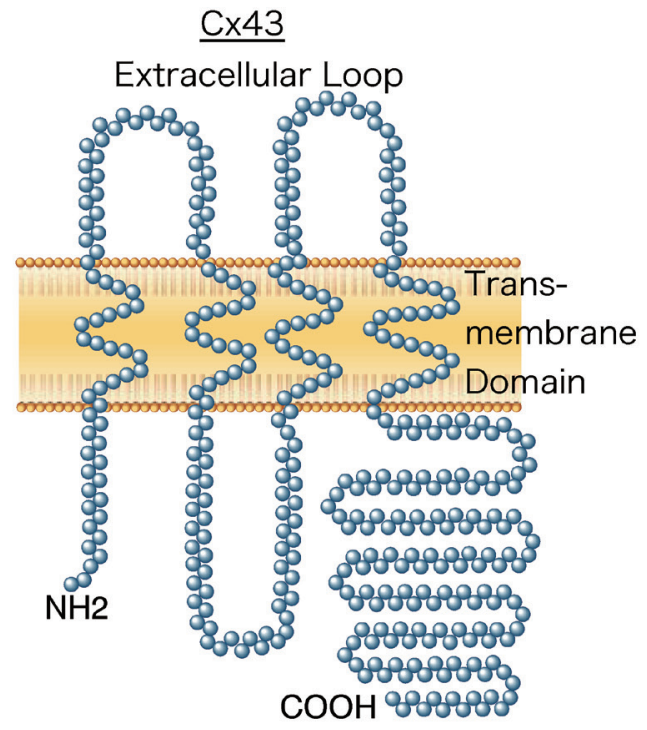

Fig. 6 Role of $\mathrm{Cx} 43$ in gap junction of bone tissue. a, Gap junctions in the skeleton; b, Structure of $\mathrm{Cx} 43$.

proliferation and differentiation ${ }^{14)}$.

It is noteworthy that $\mathrm{Cx} 43$-mediated gap junctional intercellular communications can upregulate the expression of osteoblastic differentiation markers, such as osteocalcin and bone sialoprotein ${ }^{19}$. Furthermore, genetically modifying $\mathrm{Cx} 43$ and gap junctional intercellular communication by transfection with $\mathrm{Cx} 43$ antisense cDNA alters the phenotypic characteristics of osteoblasts, which include alkaline phosphatase activity and gene expression of osteopontin, osteocalcin, and Cbfa1, suggesting that $\mathrm{Cx} 43$ expression contributes at least partially to osteoblastic differentiation ${ }^{20)}$.

Concerning to the role of tissue repairing by $\beta$-TCP, it has been reported that $\mathrm{Cx} 43$ has a novel role in modulating wound healing in fibrotic scar tissue and plays a role in the regeneration of cardiac muscle after tissue injury ${ }^{21}$. Interestingly, microvascular remodeling was associated with $\mathrm{Cx} 43$ upregulation $^{22)}$. Moreover, $\mathrm{Cx} 43$ deficiency in mice causes the dysregulation of coronary vasculogenesis. These findings suggest an essential role for $\mathrm{Cx} 43$ in coronary vasculogenesis and vascular remodelling ${ }^{23)}$. Furthermore, in terms of the biodegradable activity of $\beta$-TCP with $\mathrm{Cx} 43$, Schilling et $a l{ }^{24)}$ determined that gap junctional communication is important for the fusion of human mononuclear precursor cells to osteoclasts, and that gap junctional Cx43 might play an important role in the regulation of multinuclearity of osteoclasts in vivo. Taking these reports together with our findings, we propose that $\beta$ TCP may be involved in vascular remodeling, wound healing and that the biodegradability of $\beta$-TCP is mediated through $\mathrm{Cx} 43$ expression.

However, the underlying mechanisms of direct or indirect $\beta$-TCP-stimulated wound healing and bone formation remain unclear. The loss of gap junctionmediated cell-to-cell communication leads to compromised development in many tissues and organs, because cells constantly interact through gap junctions to coordinate tissue functions and homeostasis. Interestingly, it has been proposed that $\mathrm{Cx} 43$ plays a role as a signaling platform for increasing the volume and spatial distribution of regenerated tissue in three dimensions in vivo ${ }^{25}$. Therefore, another hypothesis may be put forward that $\beta$-TCP may stimulate cell-cell communication between cells such as osteoblasts, osteocytes and osteoclasts and their progenitor cells, and leads to increased $\mathrm{Cx} 43$ expression and the formation of more gap junction channels to bolster the signaling network. Transcriptomic data analysis may be useful to resolve this mechanism.

\section{ACKNOWLEDGMENTS}

This study was supported in part by the "Academic Frontier" Project for Private Universities: a matching fund subsidy from the Ministry of Education, Culture, Sports, Science and Technology, 2007-2011, and by a Grant-in-Aid for Scientific Research from the Japanese Society for the Promotion of Science (B21390497).

\section{REFERENCES}

1) Friedlaender GE. Current concepts review: Bone grafts: The basic science rationale for clinical application. J Bone Joint Surg Am 1987; 69: 786-790.

2) Yaszemski MJ, Payne RG, Hayes WC, Langer R, Mikos AG. Evolution of bone transplantation: molecular, cellular, and tissue strategies to engineer human bone. Biomaterials 1996; 17: 175-185. 
3) Jarcho M. Calcium phosphate ceramics as hard tissue prosthetics. Clin Orthop Relat Res 1981; 157: 259-278.

4) Kondo N, Ogose A, Tokunaga K, Ito T, Arai K, Kudo N, Inoue $\mathrm{H}$, Irie H, Endo N. Bone formation and resorption of highly purified $\beta$-tricalcium phosphate in the rat femoral condyle. Biomaterials 2005; 26: 5600-5608.

5) Cheng L, Ye F, Yang R, Lu X, Shi Y, Li L, Fan H, Bu H. Osteoinduction of hydroxyapatite/beta-tricalcium phosphate bioceramics in mice with a fractured fibula. Acta Biomater 2010; 6: 1569-1574.

6) Shirasu N, Ueno T, Hirata Y, Hirata A, Kagawa T, Kanou M, Sawaki M, Wakimoto M, Ota A, Imura H, Matsumura T, Yamada T, Yamachika E, Sano K. Bone formation in a rat calvarial defect model after transplanting autogenous bone marrow with $\beta$-tricalcium phosphate. Acta Histochem 2010; 112: 270-277.

7) Ogose A, Hotta T, Kawashima H, Kondo N, Gu W, Kamura T, Endo N. Comparison of hydroxyapatite and beta tricalcium phosphate as bone substitutes after excision of bone tumors. J Biomed Mater Res B 2005; 72: 94-101.

8) Zerbo IR, Bronckers AL, de Lange GL, van Beek GJ, Burger EH. Histology of human alveolar bone regeneration with a porous tricalcium phosphate. A report of two cases. Clin Oral Implants Res 2001; 12: 379-384.

9) Cotrina ML, Lin JH, Alves-Rodrigues A, Liu S, Li J, Azmi-Ghadimi H, Kang J, Naus CC, Nedergaard M. Connexins regulate calcium signaling by controlling ATP release. Proc Natl Acad Sci USA 1998; 95: 15735-15740.

10) Brkovic BM, Prasad HS, Konandreas G, Milan R, Antunovic D, Sándor GK, Rohrer MD. Simple preservation of a maxillary extraction socket using beta-tricalcium phosphate with type I collagen: preliminary clinical and histomorphometric observations. J Can Dent Assoc 2008; 74: 523-528.

11) Beyer EC, Paul DL, Goodenough DA. Connexin family of gap junction proteins. J Membr Biol 1990; 116: 187-194.

12) Evans WH, Martin PE. Gap junctions: structure and function. Mol Membr Biol 2002; 19: 121-136.

13) Dbouk HA, Mroue RM, El-Sabban ME, Talhouk RS. Connexins: a myriad of functions extending beyond assembly of gap junction channels. Cell Commun Signal 2009; 7: 1-17.
14) Gramsch B, Gabriel HD, Wiemann M, Grümmer R, Winterhager E, Bingmann D, Schirrmacher K. Enhancement of connexin 43 expression increases proliferation and differentiation of an osteoblast-like cell line. Exp Cell Res 2001; 264: 397-407.

15) Civitelli R. Cell-cell communication in the osteoblast/ osteocyte lineage. Arch Biochem Biophys 2008; 473: 188-192.

16) Stains JP, Civitelli R. Gap junctions in skeletal development and function. Biochim Biophys Acta 2005; 1719: 69-81.

17) Doty SB. Morphological evidence of gap junctions between bone cells. Calcif Tissue Int 1981; 33: 509-512.

18) Ishihara $Y$, Kamioka H, Honjo T, Ueda H, Takano-Yamamoto $\mathrm{T}$, Yamashiro T. Hormonal, $\mathrm{pH}$, and calcium regulation of connexin 43-mediated dye transfer in osteocytes in chick calvaria. J Bone Miner Res 2008; 23: 350-360.

19) Lecanda F, Towler DA, Ziambaras K, Cheng SL, Koval M, Steinberg TH, Civitelli R. Gap junctional communication modulates gene expression in osteoblastic cells. Mol Biol Cell.1998; 9: 2249-2258.

20) Li Z, Zhou Z, Saunders MM, Donahue HJ. Modulation of connexin43 alters expression of osteoblastic differentiation markers. Am J Physiol Cell Physiol 2006; 290: C1248-1255.

21) Gourdie RG, Ghatnekar GS, O'Quinn M, Rhett MJ, Barker RJ, Zhu C, Jourdan J, Hunter AW. The unstoppable connexin43 carboxyl-terminus: new roles in gap junction organization and wound healing. Ann N Y Acad Sci 2006; 1080: 49-62

22) Bellafiore M, Sivverini G, Palumbo D, Macaluso F, Bianco A, Palma A, Farina F. Increased cx43 and angiogenesis in exercised mouse hearts. Int J Sports Med 2007; 28: 749-755.

23) Walker DL, Vacha SJ, Kirby ML, Lo CW. Connexin 43 deficiency causes dyasregulation of coronary vasculogenesis. Dev Biol 2005; 284: 479-498.

24) Schilling AF, Filke S, Lange T, Gebauer M, Brink S, Baranowsky A, Zustin J, Amling M. Gap junctional communication in human osteoclasts in vitro and in vivo. $\mathrm{J}$ Cell Mol Med 2008; 12: 2497-2504.

25) Rosselló RA, Wang Z, Kizana E, Krebsbach PH, Kohn DH. Connexin 43 as a signaling platform for increasing the volume and spatial distribution of regenerated tissue. Proc Natl Acad Sci USA 2009; 106: 13219-13224. 